\title{
Rules and Practices of Women's Inheritance Rights in Islam: Bangladesh Perspective
}

\author{
Md. Mostofa \\ Senior Lecturer \& Coordinator \\ Law Department \\ Bangladesh University, Bangladesh \\ E-mail: mostofa.bu@gmail.com
}

\begin{abstract}
The study aims to map the status of women right of inheritance in Bangladesh with reference to Islamic injunctions and social practice. For ideal status verses of Holy Quran and traditions of Holy Prophet regarding women right of inheritance are collected. The study concludes that we see most of the people of Bangladesh are reluctant to follow Islamic principles properly with reference to women right of inheritance. Who give women inheritance among of them majority families does not give women inheritance rather provide cash or kind in lieu of their actual shares. Even our society consider dowry as substitute of women right of inheritance. Economic dependency on men, fear of social breakup and conflicts with family and deficiency of proper Islamic knowledge are the reasons for women not to press for their share. Religious scholars should be involved to teach the masses to fulfill their religious obligation of providing actual share of inheritance to women.
\end{abstract}

Keywords: Women right of Inheritance, Bangladesh Society, Islamic teachings

\section{Introduction}

Pre-Islamic Arab culture and normative structure was male dominated and did not favour women in almost every field including property rights. Women had no right to inherit property from father or husband. The Arab had a principle that only those will inherit who can ride horse and can fight in the battle field. ${ }^{1}$ By that time, this principle clearly favored to men and disfavored to women with reference to the right of inheritance. Similarly Arabs used to deprive women from the right of inheritance in pre Islamic society and this has been expressed in the book of Tafseer Al Thubar² as-

"In pre Islamic traditions women had no assured right of inheritance, which in many cases was a matter between men, the men of the husband's clan or her own relatives When a man lost his father, brother or son and that person left a widow, the heirs used to take advantage of the privilege of the dowry paid by the dead man. They used to deprive women of the right to the part of inheritance constituted by dowry."

In order to realize the status of women, Islam grants her different type of rights like right to life, education, marriage, dower, maintenance, divorce etc. Among these rights one is the right of inheritance. Islam entitles both men and women to inherit from the deceased person. However, the shares of men and women are different in inheritance. These shares are justifiable in Islamic society, keeping in view the status and role of men and women in Islamic society. It is in the Holy Quran ${ }^{3}$ that men and women have shares in inheritance.

'To men ( of the family) belongs a share of that which parent and near kindred leave and to women a share of that which parents and near kindred leave whether it be little or much- a determinate share'.

It is crystal clear from the above verse of the Holy Quran that Islam entitles women the right of inheritance in the legacy of deceased person. In other verses of Surah Al- Nisa 11, 12, 176, the shares of wife, mother, sister and daughter in different cases are mentioned clearly. There are a number of traditions/ Hadiths of the Holy Prophet Muhammad (PBUH) regarding inheritance, women inheritance, shares of women in inheritance and traditions stressing muslins to give heirs (men and women) their share in legacy. Islam is a complete code of life which not

\footnotetext{
${ }^{1}$ Aalosi, Shahabud Din Mehmood,Tafseer Roohul-Manni, p. 210, Darul Kutab Ilmiya,Beruit, 1415 h.

${ }^{2}$ Al Thubari, Abu Jafar Muhammad Bin Jareer, Tafseer Al Thubar p. 10, Moassatur Rissala, 1420h/2000

${ }^{3}$ Surah Al Nisa4:7
} 
only provides rather ensures social space to women in Islamic society. ${ }^{4}$ In Islamic society men (father and husband) are responsible to provide food, cloth and shelter to female members of family. Women can earn money with the consent of her husband and earned money is her right. Likewise economic status of women is safeguarded by providing women right of inheritance and other property rights. Although Islamic injunctions are clearly about women right of inheritance but these are somehow ideal statuses of women inheritance. We are living in Bangladesh and we have own customs, traditions and practices. Sometime people of Bangladesh prefer their culture or own practices over religion in different matters. If we talk about women inheritance than the real status of women inheritance is much different from the ideal status. ${ }^{5}$ Though Islam entitles women the rights of inheritance but usually, most of the people of Bangladesh are reluctant to give women the right of inheritance. ${ }^{6}$ In this case, Bangladesh practices their culture and is reluctant to follow the religious teachings. ${ }^{7}$ The issue is having economic aspect well as it is a gendered one. As it involves women and men dominated social structure cannot be ignored in this regard. ${ }^{8}$ In many cases inheritance right of women are either ignored or altered beyond recognition. Fight occurs and families break off to form new nuclear kin units which often results in self-perpetuating blood feuds. ${ }^{9}$

\section{Objectives of the Research}

The objectives of the research are as follows:

- To highlight and analyze the actual inheritance practices among the Muslim society in Bangladesh.

- To identify and enumerate the inheritance rights guaranteed to Muslim women according to textual sources (Quran and Hadith) and from the tradition of early Muslim society.

- To highlight the causes why women are excluded from inheritance.

- To aware Muslim society for nonpayment of women inheritance rights.

- To give some recommendations Muslim society to remove their traditional mentality about women's inheritance right.

\section{Methodology of the Research}

The method approach is used conceptual approach and comparative approach. The researcher focused on reading, understanding, and studying the primary and secondary legal material such as articles, classical and modern books, newspapers, and websites. Along with this, verses of Holy Quran and Hadith (the tradition of Prophet Mohammad) are referred to in this research. The researcher observes the traditional practice of inheritance of society of Bangladesh. The researcher shows in this paper the Quran and Hadith what say about the rights of women inheritance and what the consequences of the transgressor who transgress the traditions of holy Quran and Hadith related women rights in inheritance. The researcher also shows some recommendations to emancipate the traditional practice of Bangladesh.

\section{Discussion on the Ideal Status of Women Right of Inheritance in Islam}

Islam grants both men and women the right of property inheritance. The shares of both men and women in different relations and cases are clearly mentioned in the Holy Quran and traditions of the Holy Prophet Muhammad Peace Be upon Him. The regulation set in the Holy Book is used as the basis of distribution of the deceased properties in Islam.

\section{Verses of Holy Quran Regarding Inheritance in Islam}

Islam grants both men and women for right of property inheritance. It is stated in Holy Quran that: "From what is left by parents and those nearest related there is a share for men and a share for women, whether the property be small or large, a determinate share. ${ }^{10 "}$ "In Islam, the share of a man is equal to the share of two women.

It is stated clearly in the Holy Quran, "Allah (thus) directs you as regards your children's (inheritance): to the male, a portion equal to that of two females. If only daughters, two or more, their share is two-thirds of the inheritance. If

\footnotetext{
${ }^{4}$ Khan, H. (1980). Islamic Law of Inheritance: A Comparative Study with Emphasis on Contemporary Problems. Lahore Law Times Publications; Lahore: p. 44--- Khurshed,A.( 1993) Islam its meaning and message, the Islamic foundation. P.141,142

${ }^{5}$ Ahmad, M. Batool, M \& Sophia F. Dziegielewski (2016): State of Inheritance Rights: Women in a Rural District in Pakistan, Journal of Social Service Research, DOI: 10.1080/01488376.2016.1177633

${ }^{6}$ Khawar, M,Noshirwani, M.(2007) A scoping study on Women's access and rights to land and property In Pakistan. Conducted by international development research centre--- Mashal,F. (2007) A base line research study on Women inheritance rights in district Bannu. Conducted by community development program.

${ }^{7}$ Aisha, M. (2008). An investigation into women inheritance. M.A. Thesis, Deptt. of Rural Sociology. Agric. Univ. Peshawar, Pakistan--- Wisal, K. and M. Inam. (2006).

${ }^{8}$ Muhammad, 2011; NCSW 2005

${ }^{9}$ Ahmad, A. Mart,D(1984), Islam in tribal societies: From the atlas to the Indus. Rout ledge: P. 269

${ }^{10}$ Surah Al-Nisa 4: 7
} 
only one, her share is a half. For parents, a sixth share of the inheritance to each, if the deceased left children. If no children and the parents are the (only) heirs, the mother has a third. If the deceased has brothers (or sisters) the mother has a sixth. After payment of legacy and debts ye know not whether the parents or your children are nearest to you in benefit. These are settled portions ordained by Allah, and Allah is All Knowing, All Wise. ${ }^{11 "}$

In Islam the shares of different relatives are specified in the following verse of the Holy Quran, "In what your wives leave, your share is a half, if they leave no child. But if they leave a child, ye get a fourth, after payment of legacies and debt. In what ye leave, their share is a fourth, if ye leave no child. But if ye leave a child, they get an eight, after payment of legacies and debts. If the man or woman whose inheritance is in question, has left neither ascendants nor descendants, but has left a brother or a sister, each one of the two gets a sixth. But if more than two, they share in a third, after payment of legacies and debts, so that no loss is caused. Thus is it ordained by Allah, and Allah is Allknowing, Most Forbearing. ${ }^{12 "}$

The inheritance of a person who leaves no descendants or ascendants as heirs is dealt in the light of below verse of the Holy Quran.

"They ask thee for a legal decision. Say: Allah directs (thus) about those who leave no descendants or ascendants as heirs. If it is a man that dies, leaving a sister but no child, she shall have half the inheritance. If (such a deceased was) a woman, who left no child, her brother takes her inheritance. If there are two sisters, they shall have two thirds of the inheritance (between them). If there are brothers and sisters, (they share), the men having twice the share of the female. Thus doth Allah make clear to you (His Law). ${ }^{13 "}$

Another verse of the Holy Quran regarding women inheritance is as under

"O ye who believe! Ye are forbidden to inherit women against their will. ${ }^{14,}$

Allah also directs about the inheritance of orphans in the following ways:"Make trail of orphans until they reach the age of marriage; if then ye find sound judgment in them, release their property to them; but consume it not wastefully, nor in haste against their growing up. If the guardian is well-off, let him claim no remuneration, but if he is poor, let him have for himself what is just and reasonable. When ye release their property to them, take witness in their presence: but ALL-Sufficient is Allah in taking account. ${ }^{15,}$

\section{Hadiths of the Holy Prophet Muhammad (SAW) Regarding Women Right of Inheritance}

Islam bestows both men and women for right of property inheritance. The shares of both men and women in different relations and cases are clearly mentioned in the traditions of the Holy Prophet Muhammad peace be upon him. Following are some traditions of the Holy Prophet Muhammad Peace Be upon Him regarding women right of inheritance.

\subsection{About Right of Father, Mother, Wife and Husband}

"Ibn 'Abbas narrates: The custom (in old days) was that the property of the deceased would be inherited by his off springs; as for the parents (of the deceased), they would inherit by the will of the deceased. Then Allah cancelled from that custom whatever He wished and fixed for the male double the amount inherited by the female, and for each parent a sixth (of the whole legacy) and for the wife an eighth or fourth and for the husband a half or a fourth. ${ }^{16}$

\subsection{About Right of Daughter}

Jabir ibn 'Abdullah narrates: We went out with the Messenger of Allah (SAW) and came to a woman" of the Ansar in al-Aswaf. The woman brought her two daughters, and said: Messenger of Allah, these are the daughters of Thabit ibn Qays who was killed as a martyr when he was with you at the battle of Uhad, their paternal uncle has taken all their property and inheritance, and he has not left anything for them. What do you think, Messenger of Allah (SAW)? They cannot be married unless they have some property. The Messenger of Allah (SAW) said: Allah will decide regarding the matter. Then the verse of Surah an Nisa' was revealed: "Allah (thus) directs you as regards your children's (inheritance)." Messenger of Allah (SAW) said: Call to me the woman and her husband's brother. He then said to their paternal uncle: Give them two-thirds and their mother an eighth, and what remains is yours. ${ }^{17}$ About Share of a Granddaughter with daughter:

\footnotetext{
${ }^{11}$ Surah Al-Nisa4: 11

${ }^{12}$ Surah Al-Nisa4: 12

${ }^{13}$ Surah al-Nisa 4:176

${ }^{14}$ Surah Al-Nisa4: 19

${ }^{15}$ Surah an -Nisa',4:6

${ }^{16}$ Sahih al-Bukhari, $2542 C D$

${ }^{17}$ SunanAbiDawud, 2505 CD
} 
Hudhayl ibn Shurahbil narrates: Abu Musa was asked regarding (the inheritance of) a daughter, a son's daughter, and a sister. He said, "The daughter will take one-half and the sister will take one-half. If you go to Ibn Maswud, he will tell you the same." Ibn Maswud was asked and was told of Abu Musa's verdict. Ibn Maswud then said, "If I give the same verdict, I would stray and would not be of the righty -guided. The verdict I will give in this case, will be the same as the Prophet did, i.e. one- half is for daughter, and one-sixth for the son's daughter,i.e.Both shares make two thirds of the total property; and the rest is for the sister." After wards we came to Abu Musa and informed him of Ibn Maswud verdict, whereupon he said, "So, do not ask me for verdict, as long as this learned man is among you. ${ }^{18,}$

\subsection{About Right of Grandmother}

Ibn 'Abbas narrates: the Prophet gave to the grandmother one - sixth. ${ }^{19}$

Ibn Buraydah reports from his father: The Prophet (SAW) appointed a sixth to a grandmother if no mother is left to inherit before her. ${ }^{20}$

\subsection{About Right of Mother with Surviving Spouse}

ZaydibnThabit, in the case of a woman who had died leaving behind her husband and her parents, gave the husband one-half of tarikah and the mother one-third of the remainder. ${ }^{21}$

'Amir ash-Shabi narrates that 'Ali, in a case of a wife and parents said; the wife will go get one-fourth of the tarikah, the mother one-third of the remainder, and the father the remaining shares. ${ }^{22}$

\subsection{About Right of Sister with Daughter}

ZaydibnThabit ruled that when there are surviving sisters and daughters, the sisters should be treated asabah(heirs with no fixed shares) and should receive only the remainder. ${ }^{23}$

\section{Why Women are Disinherited from the Property of Deceased in the Society of Bangladesh?}

Discrimination against women about inheritance is a burning issue in our society. Islam grants for women specific directions about the right of inheritance in property of deceased. The right of inheritance for women is given by Allah. But we the people are reluctant to fulfill the directions of Allah. All most people of Bangladesh are aware of the provisions of women's rights of inheritance but they are not ready to give the women the full share of inheritance. People will give the share properly of inheritance to women, it is comparatively low ratio. Many times women get their rights through litigation. Muslim succession law is also applicable in Bangladesh. Bangladesh courts are implementing sharia law about inheritance. Nevertheless, I shall try to disclose the causes or status in the following why People are reluctant to give the right of inheritance to women.

- Disinheriting women is general practice of our society. It is continue generation to generation.

- Our society consider dowry as substitute of women right of inheritance. It is observed that in many cases the male members argue that women are given dowry at the time of marriage. Money is spent on purchase of dowry items like clothes, jewelry, crockery, furniture and other home related articles. Although right of dowry can be a reason for half shares of women in property but considering it as a substitute is wrong and against Islamic commandments.

- Sometimes Women are persuaded to relinquish their due right of inheritance by various tactics. Women are persuaded in cash or kind in lieu of actual their share ordained by Allah. Those female who have taken shares are not supported even in case of emergency and conflicts.

- Parents exclude women from inheritance by transferring property to sons during their life time. To avoid the tension and future demand by daughters, parent (father) transfer property to their sons during their lifetime.

- Demand of share in inheritance by women is considered as bad.

- Unawareness may be a reason due to which women do not demand their right of inheritance.

- Dependency on brothers is a reason due to which women avoid demanding their share in inheritance.

- Due to fear of quitting relationship, demand of share by women results in conflict, male dominancy are the reason for women to avoid demanding their share in inheritance.

- Anticipated dependence on brothers is the cause for women to avoid demand of this right. Women are not independent in our society. They have to solely rely upon their brother for many tasks and cases.

${ }^{18}$ Sahih al - Bukhari, 6239 CD

${ }^{19}$ Sunan Ibn Majah, 2715 CD

${ }^{20}$ Sunan Abi Dawud, 2508 CD

${ }^{21}$ (Sunan ad-Darimi, 2744 CD)

${ }^{22}$ (Sunan ad-Darimi, 2745 CD)

${ }^{23}$ (Sunan ad-Darimi, 2754 CD) 
- Women ask for the help of law court that women get their share in inheritance through litigation. It is obvious that litigation results in disturbance of social relations and they do not support each other even in case of emergency.

- It is to be noted that in our society women are deprived on the bases of this false mala fide justification.

- Economic gains and customary practices are given more importance and preference over Islamic injunctions.

- Feeling of fear among women, lack of awareness, male hegemony and dependence on male and patriarchal setup are some of the key reasons for non-demand of this right.

8. Consequences of Violating the Women's Rights of Inheritance

It should be noted that when a Muslim dies, the obligations to be taken out of his estate (in order of priority are):

Those who disrespect the law of inheritance are regarded as snatchers of others' property and rights and are considered transgressors of Islamic Shariah-be their partially or wholly. Allah has given a severe warning against the violation of the law of inheritance. Allah the Exalted in power, he said, just after the description of inheritance, in the Qur'an:

"'But those who disobey Allah and His Messenger and transgress His limits will be admitted to a fire, to abide therein: and they shall have a humiliating punishment. ${ }^{24,}$

Some severe warning traditions against the violation of the law of inheritance are mentioned below by the messenger of Allah.

Saalim ( son of Abdullah) narrated from his father and his father from the messenger of Allah that the prophet had said '"whosoever usurps anything of other's illegally without his permission, he, on the Day of Judgment, would be thrust into the seventh layer of the earth. ${ }^{25,}$

It is narrated by Abu Huraira (R.A) that the Holy Prophet said that; "Sometimes it happens that a man or a woman spends his sixty years life in the obedience of Allah but whenever death approaches them. So in making will, they deprive their heirs. These people will be put into hell. ${ }^{26 "}$

Similarly another tradition narrated by Anas (R.A). that the Holy Prophet said: "Those who deprive their heirs from their shares in inheritance, Almighty Allah will deprive them from paradise. ${ }^{27,}$

The prophet of Allah said ''Beware! Never do injustice to anyone. No property of a person is lawful for others without his cordial consent. ${ }^{28,}$

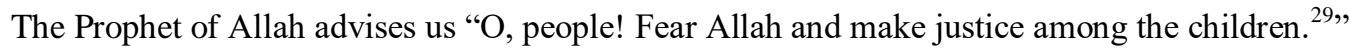

Narrated Abu Hurairah: The Messenger of Allah (peace be upon him) said: “A believer's soul remains in suspense (cannot enter Paradise) until all his debts are paid off. ${ }^{30,}$

Narrated Muhammad ibn Abdullah ibn Jahsh: The Messenger of Allah (peace be upon him) said: "By Him in whose hand Muhammad's soul is, if a man were to be killed in Allah's path then come to life, be killed again in Allah's path then come to life, and be killed once more in Allah's path then come to life owing a debt, he would not enter Paradise till his debt was paid. ${ }^{31,}$

\section{Recommendation}

Allah declares reward for those who obey Allah and His Messenger. "Those are limits set by Allah; those who obey Allah and His Messenger will be admitted to Garden with rivers flowing beneath, to abide therein (forever) and that will be the Supreme achievement. ${ }^{32,}$

On the basis of above verses of the Holy Qur'an, I draw following recommendations-

- Every Muslim should know Inheritance because our Prophet (SAW) has also constantly stressed upon Muslim to learn the law of inheritance and transmit it to others. He categorically stated:

"Learn the laws of inheritance and teach them to the people, for they are half of the knowledge."

\footnotetext{
${ }^{24}$ Surah an- Nisa, '4:14)

${ }^{25}$ (Fatawa Mazabirul Uloom)

${ }^{26}$ Al Tibrizi, Abu Abdul Ullah Muhammad Bin Abdul Ullah, MishkatulMasabeekh P.26, Al Muktabul Islami, Beruit, 1985

${ }^{27}$ Mishkat, p. 266

${ }^{28}$ Fatawa Mazabirul Uloom

${ }^{29}$ (Fatawa Raheemiyah, Vol.2, p.259, Vol. 6, p. 45)

${ }^{30}$ Ahmad, Ibn Majah, and Tirmidhy Collections.

${ }^{31}$ Bukhari Collection

${ }^{32}$ Surah an- Nisa', 4:13

${ }^{33}$ Sunanibn Majah
} 
- Islamic Teaching on Inheritance should give more emphasis so that any Muslim cannot disinherit other. He or she also cannot be disinherited from others. Because in one Hadith of the Holy Prophet it is stated that those who disinherit their children will be put into hell.

- Every Muslim should obey the limits of Allah so that he or she can be admitted to Garden with rivers flowing beneath. ${ }^{34}$

- Government should take the responsibility of distribution of deceased property to heirs.

- Government can attribute punishment for the transgressor of inheritance provisions.

- Government and non-government organizations can increase social awareness with print media and electronic media.

- Especially women should be more aware of their inheritance rights. Because these right are ordained for them by Allah.

\section{Conclusion}

It can be concluded that our society is a male dominated and gender biased code of life. The comparison of Islamic injunctions and our societal practice with reference to women share of property inheritance show that our society dominates Islamic teachings.

Instead of high level of awareness of Islamic teachings about women right of inheritance, our society does not confer this right which further approves the conclusion we drew from the current study. Our social and societal and social structure has very limited social space for women in economic and property ownership. It discourages any move that provide space to women to get property ownership through inheritance. Such ownership is stopped either through dowry, transfer of property to sons by father during life time or by social boycott rather social exclusion of women from family.

To sum up, traditional thinking, economic gains, male dominancy and dependency of women on men are some key responsible factors not to give the share of right of inheritance to women.

\section{References}

\section{Al Quran}

Surah al-Nisa 4:176

Surah an-Nisa', 4:6

Surah Al-Nisa 4: 7

Surah Al-Nisa4: 11

Surah Al-Nisa4: 12

Surah Al-Nisa4: 19

Surah an- Nisa,' 4:14

Surah an- Nisa', 4:13

\section{Hadith}

Sahih al - Bukhari, 2542 CD

SunanAbi Dawud, 2505 CD

Sahih al - Bukhari, 6239 CD

Sunan Ibn Majah, 2715 CD

Sunan Abi Dawud, 2508 CD

Sunan ad-Darimi, 2744 CD

Sunan ad-Darimi, 2745 CD

Sunan ad-Darimi, 2754 CD

Fatawa Mazabirul Uloom

Al Tibrizi, Abu Abdul Ullah Muhammad Bin Abdul Ullah, Mishkatul Masabeekh P.26, Al Muktabul Islami, Beruit, 1985

Mishkat, p. 266

Fatawa Mazabirul Uloom

Fatawa Raheemiyah, Vol.2, p.259, Vol. 6, p. 45

Ahmad, Ibn Majah, and Tirmidhy Collections.

Bukhari Collection

Sunanibn Majah

\section{Books and Journals}

Aalosi, Shahabud Din Mehmood,Tafseer Roohul-Manni, p. 210, Darul Kutab Ilmiya,Beruit, 1415 h.

\footnotetext{
${ }^{34}$ (Surah an- Nisa', 4:13)
} 
Ahmad, A. Mart,D(1984), Islam in tribal societies: From the atlas to the Indus. Rout ledge: P. 269

Ahmad, M. Batool, M \& Sophia F. Dziegielewski (2016): State of Inheritance Rights: Women in a Rural District in Pakistan, Journal of Social Service Research, DOI: 10.1080/01488376.2016.1177633

Aisha, M. (2008). An investigation into women inheritance. M.A. Thesis, Deptt. of Rural Sociology. Agric. Univ. Peshawar, Pakistan--- Wisal, K. and M. Inam. (2006).

Al Thubari, Abu Jafar Muhammad Bin Jareer, Tafseer Al Thubar p. 10, Moassatur Rissala, 1420h/ 2000

Khan, H. (1980). Islamic Law of Inheritance: A Comparative Study with Emphasis on Contemporary Problems. Lahore Law Times Publications; Lahore: p. 44--- Khurshed,A.( 1993) Islam its meaning and message, the Islamic foundation. P.141,142

Khawar, M,Noshirwani ,M.(2007) A scoping study on Women's access and rights to land and property In Pakistan. Conducted by international development research centre.

Mashal,F. (2007) A base line research study on Women inheritance rights in district Bannu. Conducted by community development program.

Muhammad, 2011; NCSW 2005

\section{Copyrights}

Copyright for this article is retained by the author(s), with first publication rights granted to the journal.

This is an open-access article distributed under the terms and conditions of the Creative Commons Attribution license (http://creativecommons.org/licenses/by/4.0/) 